\title{
Essential Trial Document
}

National Cancer Institute

\section{Source}

National Cancer Institute. Essential Trial Document. NCI Thesaurus. Code C142540.

A document that demonstrates the compliance of the investigator, sponsor, and monitor of a clinical trial with all applicable regulatory requirements and the standards of Good Clinical Practice. 